copied from my note-book. It was evidently meant to indicate the continuation of the tail towards the nucleus, as seen on subsequent mornings, when farther from the sun. $D$ is the terminal edge of the tail, as sharp as the outer limb of the moon, and of fullest strength of lustre. Altogether it formed a rather appalling apparition. Clouds soon obscured it. No farther view was obtained for two or three days, when the end of the tail had assumed the usual misty, indefinite outline.

The conclusion forced upon my mind was that the comet, having parted with its tail in its rapid turn at the periheiion, was seen in the act of forcing out a new one ahead of itself, in a solid bank of vapour, the front of which might be compare 1 to the wall of water that heads a freshet in a stream. Another resemblance suggested was that of the solid-looking outline of an up-rolling cumulus cloud.

I will add hereto a statement made to me at the time by the Rev. Hiram Bingham, a distinguished pioneer missionary to the Gilbert Islands. He saw the comet about a week earlier than myself, from Kaneohe, on the east side of Oahu. Both he and his wife observed rvaves of prismatic colours running outward along the brilliant tail. Mr. Bingham is a highly ciltivated person, and having commanded the missionary ship for part of two years, is accustomed to lunar and stellar observation. I was led at the time to believe that there was no optical illusion in what he saw.

Honolulu, June $3^{\circ}$.

\section{Copepoda as an Article of Food.}

Prof. Herdian's practical demonstration at the North Cape confirms a theory I have long held, that the Copepoda, which abound in every ocean, sea, and lake, might be largely and advantageously made available for human food. It is well known that the species Calanus finmarchicus, so aburdant in our northern seas, forms the chief food of the Greenlanc? whale. Our own immediate coasts abound in this and other equally edible species. During a recent dredging cruise round the Isle of Man, each pull of the tow-net contained thousands of another and larger species of Copepod, Anomalocera pat:rsonii; and Dr. John Murray has found that a still larger species, Eucheta norvegica, is plentiful in the lower depths of several Scotch lochs.

A number of finely-meshed trawls, used off the west coast of Ireland, would, I am convinced, furnish excellent food for starving multitudes in time of need.

A propos of the distribution of Copepoda, my attention was called a few days ago by the Mayor of Bootle to the filer-beds of the town salt-water baths, which he said were swarming with Entomostraca. The water is supplied direct from the river, and examination showed the presence of Copepoda in enormous quantities, the bulk of them being Eurytemora hirundo, a species only once before taken in Britain, and then in near proximity to Bootle. Probably other filter-heds are equally prolific, and may prove valuable hunting grounds, the Copepoda undoubtedly acting as scavengers in keeping the water pure from putrefaction.

Liverpool, July 24 .

I. C. Thompson.

\section{Meteorological Phenomenon.}

I HAVE received in a letter from a friend residing in Boraston, Shropshire, the following account of a remarkably interesting meteorological phenomenon, which is well worth putting on record :- -

"We had a curious sight from this house yesterday [July 26]. It was a dead calm, but in a field just below the garden, with only one hedge between us and it, the hay was whirled up high into the sky, a column connecting above and below, and in the course of the evening we found great patches of hay raining down all over the surrounding meadows and our garden. It kept falling quite four hours after the affair. There was not a breath of air stirring as far as we could see, except in that one spot."

Francis Galton.

\section{Refraction through a Pristn.}

IN such elementary text-books on geometrical optics as I have consulted it has always seemed to me that the writers have found a difficulty in presenting a precise direct proof of the theorem that when a ray is turned out of its course by direct passage through a prism, its deviation is least when its path is symmetrical with regard to the prism.

May I ask you to consider the simple proof which I inclose, and may $I$ leave it to your judgment whether it is worth while that it should be presented to the notice of teachers in the pages of NATURE? My knowledge of text-books I cannot suppose to be exhaustive, and the arrangement of the proof which I inclose of course may not be any novelty.

\section{Radley College, Abingdon, June Ix.}

\section{JOHN H. KIRKBY.}

\section{Minimum Deviation.}

The problem is to find two rays which, passing directly through a prism near together, have their directions changed by the prism to the same amount-for in the limit, these, when brought into coincidence by change of position of the prism, will mark the course of that ray which suffers minimum deviation (experiment may be appealed to, to show that it is minimum

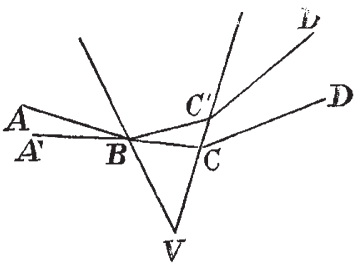

and not maximum). Let $\mathrm{ABCD}$ be the course of a ray of light through the prism whose vertex is $V$. At $B$ make the $\angle \mathrm{VBC}^{\prime}=\angle \mathrm{VCB}$, then if the ray $\mathrm{BC}^{\prime}$ is continued out of the prism on both sides, it is evident that its completion $\mathrm{D}^{\prime} \mathrm{C}^{\prime} \mathrm{BA}^{\prime}$ meets and leaves the faces of the prism at exactly the same angles as the original ray $A B C D$, only in the opposite direction. Thus the two rays $A B C D, A^{\prime} B C^{\prime} D^{\prime}$ suffer equal deviation, and because the $\triangle$ 's $V B C, V C^{\prime} B$ are similar,

$$
\therefore \mathrm{VB}^{2}=\mathrm{VC} \cdot \mathrm{VC}^{\prime} \text {; }
$$

and when the rays are so close as to practically render $C, \mathrm{C}^{\prime}$ coincident, we have $\mathrm{VB}^{2}=\mathrm{VC}^{2}$, or $\mathrm{VB}=\mathrm{VC}$ when the deviation is a minimum, i.e. the deviation is a minimum when the course of the ray makes equal angles with the sides of the prism.

[Oxford men will remember that more than twenty years ago Prof. Clifton gave a somewhat similar proof as follows :-

Since the paths $A B C D$ and $D^{\prime} C^{\prime} B N$ are similar, if one is a path of minimum deviation the other must have the same property also. Hence, since light can always travel in the reverse direction along a path, the paths

$$
\mathrm{ABCD} \text { and } \mathrm{NBC} D
$$

are both paths of minimum deviation.

But the existence of two such minima is contrary to experiment. Hence the paths must be identical, which can only be the case of the angle $\mathrm{VBC}=\mathrm{VBC}^{\prime}=\mathrm{VCB}$. - - ED.]

\section{Further Notes on the Anatomy of the Heloderma.}

Since I published in Nature (vol. xliii. p. 514), "The Poison Apparatus of the Heloderma," there has appeared from the pen of Mr. Boulenger another notable contribution to the anatomy of that genus of reptiles, entitled "Notes on the Osteology of Heloderma horridum and $H$. suspectum, with Remarks on the Systematic Position of the Helodermatide and on the Vertebræ of the Lacertilia," (P.Z.S., January 20, 1891). That paper is especially useful, inasmuch as it critically compares the vertebral columns of the two species of Lizards under consideration-a comparison which, up to the time of the appearance of Mr. Boulenger's paper, had not been made. 'To briefly recapitulate his points, Boulenger finds differences in the form of the premaxillaries of the two species, and in the number of teeth supported by those bones. He finds palatine and pterygoid teeth constantly absent in $H$. suspectum but present in $H$. horridum - a very remarkable fact. A small azygous ossification was found in the cartilage of the mandibular symphysis of $H$. horridum, "apparently the homologue of the symphysial (mento-meckelian) bones of most tailless Batrachians." This

NO. I I 35, vOL. 44] 